\title{
Lídia Jorge: territórios da paixão e da escrita
}

\author{
José Luis Giovanoni Fornos \\ (Universidade Federal do Rio Grande - FURG)
}

\section{RESUMO}

O presente trabalho aborda os romances da escritora portuguesa Lídia Jorge, enfatizando os aspectos simbólicos do espaço. Considera, sobretudo, a dimensão histórica e política dos diferentes territórios examinados pela autora. Igualmente investiga a importância da escrita na construção espacial e o predomínio da paixão - amorosa e ideológica - nos conflitos identitários vividos pelas personagens.

PALABRAS-CHAVE: romance português contemporâneo; identidade; ideologia

\section{RESUMEN}

El presente trabajo aborda las novelas de la escritora portuguesa Lídia Jorge, enfatizando los aspectos simbólicos del espacio. Considera, principalmente, la dimensión histórica y política de los diferentes territorios examinados por la autora. También investiga la importancia de la escritura en la construcción espacial y el predominio de la pasión - amorosa e ideológica - en los conflictos de identidad vividos por los personajes.

PALABRAS CLAVE: novela portuguesa contemporánea; identidad; ideología 
A variedade do topos espacial é uma das características dos romances de Lídia Jorge. Diferentes geografias, seguidas por alterações sociais e políticas, assinalam sua obra. A dimensão espacial, enquadrada histórica, física e culturalmente, afeta personagens, embriagando seus destinos, alterando-lhes o cotidiano, informando um Portugal em mutação ${ }^{1}$.

A preocupação com a diversidade dos ambientes soma-se a outras características, entre as quais destacam-se as dimensões alegórica e simbólica dos objetos, reflexões sobre a escrita, o questionamento da identidade e a figura da paixão que desperta as emoções artísticas e políticas. Tais escolhas são mediadas pela ironia, promotora do riso crítico.

Em O dia dos prodígios (1980), a comunidade rural imaginária de Vilamaninhos remete o leitor ao Algarve português. Semelhante espaço é promovido em $O$ cais das merendas (1982) e O vale da paixão (1998). Todavia, em tais exemplos, ainda que a região se repita, o conteúdo narrativo recai sobre grupos sociais distintos, marcados pelas diferenças de classe e gênero, bem como por hábitos culturais específicos. Em $O$ cais das merendas, são representadas personagens trabalhadoras que, presas à produção agrária, rumam em direção ao litoral, motivadas por novos e grandes empreendimentos. A fim de escaparem da rotina do trabalho na terra, destino histórico de pais e avós, o grupo observa na construção do Hotel Alguergue oportunidade especial de mudança.

O empreendimento turístico influencia de maneira decisiva os moradores da região, assumindo conotações alegóricas das transformações econômico-sociais ocorridas ao sul de Portugal. O conjunto arquitetônico produz múltiplos significados, ampliando perspectivas que acabam provocando conflitos, disseminadores de uma crise de pertencimento. Equiparado metaforicamente aos conventos de séculos passados, o Hotel Alguergue altera a rotina da população local, habituada a outros ritmos temporais, demarcados a partir de modelos de produção específicos. O nome do Hotel deriva de uma pedra local que, deixada como lembrança e ornamento ${ }^{2}$, transforma-se em sinal trágico. A pedra alguergue alegoriza a agonia e o prazer da paisagem territorial e humana atingidas.

Em O cais das merendas, a chegada de turistas estrangeiros ao Hotel Alguergue modifica o comportamento das personagens nativas, incentivando novos hábitos, alterando-lhes sentimentos. ${ }^{3}$ A confluência externa põe em questão a razão da existência da comunidade, dividida entre a acolhida simpática, o temor e a rejeição sumária.

A região do Algarve, em $O$ dia dos prodígios, acolhe os soldados oriundos do Movimento das Forças Armadas (MFA), promotores do 25 de Abril que, ao chegarem ao vilarejo de Vilamaninhos, anunciam novos rumos ao país, ensinando à comunidade as vantagens da Revolução dos Cravos que, segundo os militaresmilitantes, desencadeará importantes reformas, eliminando injustiças. O grupo social local, ao assistir maravilhado ao espetáculo, acredita em renovação, escapando do isolamento e esquecimento históricos. Soluções que os afastem da estagnação econômica e cultural são sonhadas pelos moradores a partir do evento, estimulando gestos que põem em xeque relações ossificadas por longa tradição.

O prodigioso dia refere-se, em especial, ao da transformação política de Portugal que, depois de quase meio século de ditadura, de limitações severas à liberdade, é conduzido à democracia. O momento político alimenta-se com novas promessas. Em $O$ dia dos prodígios, o episódio é explorado por Lídia Jorge com júbilo e ironia. Ao discursarem, improvisados em cima de um caminhão, transformando-o em palanque pedagógico e ideológico, os capitães de Abril 
entram em descompasso com as expectativas locais. Entusiasmados pela causa que defendem, os "revolucionários" esperam que os moradores apreendam com rapidez o receituário da revolução, pronunciado como milagre religioso. Embora viva a alegria contagiante da ocasião, o povo de Vilamaninhos decepciona-se quando o grupo de soldados não possui respostas à indagação da personagem Jesuína Palha que, juntamente com a comunidade, quer o esclarecimento do episódio da "cobra voadora" vivido no verão.

A ausência de respostas sugere, entre outros aspectos, dificuldades da razão revolucionária em explicar crenças seculares que cercam aquela comunidade rural. O fenômeno mágico, sinalizado pela cobra voadora, refere-se também à imagem de um Portugal mítico, à espera de forças miraculosas, capazes de salvar o país dos infortúnios; evoca a ressurreição do mito sebastianista em uma aldeia distante da capital portuguesa.

Em $O$ dia dos prodígios, outros eventos mágicos, envolvendo as demais personagens, ocorrem, porém é a chegada dos militares que sintetiza os sinais miraculosos. A revolução, embora traga alento e esperança, não traduz integralmente os sonhos dos moradores. A frase "ninguém se liberta de nada se não quiser libertar-se", repetida no decorrer da narrativa, pressupõe a necessidade de uma dupla ruptura frente às múltiplas situações de opressão. Embora se estenda a todas personagens, a proposição dirige-se especialmente às mulheres, funcionando como imperativo pedagógico-libertador nas relações com os homens. O tema da condição feminina atravessa a obra de Lídia Jorge, modelando questões políticas e históricas sob a perspectiva da mulher.

Se em $O$ dia dos prodígios e em $O$ cais das merendas a região do Algarve é exposta através do contato das comunidades locais com sujeitos advindos de outros espaços, em $O$ vale da paixão, é a chegada da personagem Walter Glória Dias às terras do pai, depois de longa ausência, que produz estranhamento no grupo familiar. A presença de Walter traz recordações que põem em risco a coesão da família Dias, assentada no comando irredutível do latifundiário Francisco, figura alegórica do período salazarista.

O romance $O$ vale da paixão abarca os últimos 50 anos da vida nacional portuguesa, interrogando, através da vivência individual, o autoritarismo, o conservadorismo do regime salazarista e sua lenta agonia. Encerra-se na década de 1980, período em que os efeitos da fragmentação ideológica e identitária causam perplexidade e desalento, mas, ao mesmo tempo, proporcionam a homens e mulheres introspecção reflexiva, momento em que a memória escrita assume papel importante na reavaliação historiográfica e ideológica.

A rememoração, elaborada na descontinuidade múltipla do fragmento, estilhaça as sínteses históricas. François Dosse (1999, p. 281) constata que, "a voga das rememorações ilustra uma nova relação com a historicidade", tornando essa última obsoleta. Para o autor, o recalcamento da história pela memória faz com que não haja maior "busca das origens para desenvolver as potencialidades do devir", mas é somente "a simples invocação do universo dos signos do passado que sobrevive no presente imutável." No entanto, após a travessia histórica efetuada através dos romances jorgeanos, objetamos a afirmação de Dosse de que "esses lugares da memória não são revisitados com a perspectiva de reconstrução", sendo considerados apenas como "restos de um passado recalcado, desaparecido".

Questionamento histórico e consciência crítica atravessam o romance $A$ costa dos murmúrios (1988) que projeta outro espaço físico e social, afastando-se do território português, assentando-se em solo africano. A guerra na África e seus 
efeitos nas relações entre homens e mulheres é um dos temas do livro. O recalcamento da guerra colonial pelo poder oficial estimula a narradora Eva Lopo, vinte anos depois, a rememorar, através de relatos e fotografias, episódios trágicos motivados pelo conflito em meio às recordações da alegria sentida em seu casamento com o soldado Luís Alex, comemorado no terraço do Hotel Stella Maris, na cidade da Beira, em Moçambique 4 .

O romance divide-se em duas partes: a primeira, composta por um conto narrado na terceira pessoa, intitulado "Os Gafanhotos", menciona a festa matrimonial de Eva Lopo e as alegrias daquele momento, secundarizando as mortes de inúmeros negros, recolhidos pelo serviço de limpeza urbana em uma praia próxima ao Hotel. Múltiplas inferências, conduzidas pelo ponto de vista de Eva Lopo, redimensionam a segunda parte do livro. O questionamento das mortes, concomitante à revelação dos bastidores das relações amorosas, é diagnosticado, buscando subtrair lacunas e silêncios encobertos pelo contexto político e pela condição identitária das personagens.

Desconhecimento e descaso, presentes na primeira parte, são sobrepostos por um olhar atento na segunda, favorecido pela maturidade e pelo distanciamento temporal. A opressão e o ressentimento são desbloqueados pela memória e escrita, elementos que estimulam Eva Lopo a um retorno crítico ao passado. Outra história marcada pela polifonia e contradição emerge, questionando conteúdos e estratégias utilizados. O fingimento e a força física como emblemas de sedução são postos em causa, à medida que são desmascarados por uma visão que põe em questão os escamoteamentos afetivos e ideológicos do poder. Imagens da coragem e da potência física masculinas, sustentadas sistematicamente na violência e mentira, são destronadas. O livro é uma acusação contra a prepotência e beligerância do discurso falo-logocêntrico ${ }^{5}$, referência ideológica à política colonial salazarista, encarnação simbólica do pai, simultaneamente, protetor e opressor.

Os romances Notícia da cidade silvestre (1984) e O jardim sem limites (1995) estão circunscritos à outra geografia. As trajetórias das personagens são capitalizadas pela cidade de Lisboa. O espaço rural e litorâneo dá lugar à paisagem urbana que traz consigo novas conotações ideológicas que afetam profundamente as relações afetivas. Em Notícia da cidade silvestre, os relacionamentos amorosos vividos por Júlia Grei refletem identidades em crise, revisitadas nas ruas, bairros e bares da cidade. A narrativa transcorre no período de 1975 a 1979, momento imediatamente posterior à Revolução dos Cravos, período em que a alegria, o medo e a perplexidade alternam-se em vista das transformações do país. A multiplicidade de experiências - políticas, afetivas e artísticas - emana por Lisboa, mostrando uma cidade diferente do seu enraizamento provincial e tranquilo, sendo agora descortinada sob os efeitos da miséria e da agitação política.

Era Outubro e vivia-se a imagem duma cidade atapetada de papéis soltos, guerras brandas de dizeres violentos, baldes de tinta na cara dos ícones uns dos outros. Mensagens ondulantes feitas antes do amanhecer e esquecidas depois do almoço. Onde encontraria Artur Salema um sítio tão propício ao desespero e à ternura como ali, à beira do Tejo, tudo a desaguar para armazéns e docas? (Jorge, 1984, p.154) 
Em O Jardim sem limites, Lisboa já não estampa em suas avenidas e bairros os conflitos políticos que cercam as personagens de Notícia da cidade silvestre. A cidade acolhe agora um grupo jovem que, sobrecarregado pelas exigências crescentes de uma sociedade do espetáculo ${ }^{6}$, permuta o amor por causas abstratas e bandeiras ideológicas de dimensões universais pelo pragmatismo artístico e econômico. O ambiente é visto "numa perspectiva mais cínica do que fanática", declara uma personagem. $\mathrm{Na}$ Baixa lisboeta, pessoas passam rápidas, "entretidas com as suas contas, olhando para os seus cheques e os seus cartões de crédito".

Se em Notícia da cidade silvestre as personagens acreditam em projetos utópicos de grande alcance coletivo, embora sinais de desencanto sejam visíveis; em $O$ jardim sem limites já não há fundamento teórico e ideológico que inspire e sustente um ideal a ser alcançado. Os sonhos coletivos de mudança social transformam-se em fragmentos privados que se revezam em importância conforme o valor de uso e de troca, assediados por corporações financeiras e midiáticas. Aos indivíduos cabe escolher o conteúdo-mercadoria que melhor se adapte ao seu "estado da alma" a fim de alcançar a felicidade pessoal. Distante, portanto, de um imaginário ideológico em que a utopia de mundo livre, igualitário, fraterno e solidário, perseguido por meio de alteração radical das relações de classes, é referência obrigatória. A crise das ideologias e da utopia é enfocada na perspectiva da personagem Eduardo Lanuit, ex-militante revolucionário:

Não sabemos mais com que sonhar. Tudo faz parte do mesmo pesadelo. Aliás, o problema é que pertencíamos a um mundo em que dois pesadelos se amenizavam um ao outro, e vice-versa. A imaginação andava sempre a viajar. Pelo menos tinhas uma estrada a percorrer. Agora, não tens para onde espairecer a imaginação nem a revolta. (Jorge, 1995, p. 249)

Contrariando romances anteriores, em que o espaço físico alia-se ao campo histórico e social em dimensões significativas e iguais, Lídia Jorge, em 1992, publica $A$ última dona, narrativa em que enfatiza os jogos do amor, reduzindo a diegese à Casa do Leborão, alegoria territorial do sujeito apaixonado. Embora referências políticas sejam mínimas, elas estão presentes através da posição e comportamento da personagem central. Os juízos de valor do engenheiro Geraldes revelam a condição de classe e gênero, somando-se ainda o papel da idade na avaliação dos fatos.

Tais identidades não somente limitam seu entendimento, mas igualmente expõem, por vezes, preconceitos no tratamento com o outro. Casado, com filhos e netos, Geraldes, um executivo importante de uma empresa hidrelétrica, apaixonase por uma jovem, convencido de que tal sentimento, que o arrebata, é transitório, uma vez que idade e experiência vão, em última instância, dominar o descontrole proporcionado por tal afeto. Planejamento e lucidez marcam sua trajetória profissional e familiar, o que para ele também potencializa e garante segurança e esperteza nos jogos afetivos extraoficiais.

A jovem personagem chama-se Ana Palma, reconhecida igualmente por Anita Scarlet. Ex-prostituta atua como cantora no restaurante do amante Fausto Maia, primo de Geraldes. O engenheiro executivo convida a garota para passar cinco dias na Casa do Leborão, local sugerido devido ao tratamento sigiloso e reservado. Todavia, Geraldes se atrasa ao encontro combinado com a jovem em virtude dos acontecimentos que envolvem a empresa. Tal fato atordoa Geraldes, 
antecipando, simultaneamente, duas características suas: comportamento inseguro diante do imprevisto e incapacidade ideológica de compreensão do universo local, isto é, o executivo não entende os frequentes suicídios de camponeses nas barragens da empresa, abalando suas convicções.

O esfarelamento identitário dos camponeses que, desamparados da terra, mergulham nas águas da represa a fim de reencontrar o território original - leia-se tradição - é uma situação inexplicável à personagem ${ }^{7}$. Os saltos interferem nas concepções ideológicas de Geraldes, convencionadas a partir da administração de conhecimentos científicos aplicados com rigor e planejamento. A ação inusitada dos camponeses escapa ao entendimento do executivo, uma vez que a "empresa havia construído um bairro com vista para o rio", oferecendo melhores condições materiais a eles ao erguer:

casas brancas e modernas em substituição das suas que eram velhas e desconjuntadas, quase pretas. Haviam reproduzido um largo com o mesmo volume, os mesmos bancos. Com todo o cuidado tinham conseguido transplantar a igreja pedra a pedra, anjo a anjo. Haviam mesmo transferido os mortos, osso a osso, campa a campa para um novo campo santo, e ainda tinham pago quinhentos contos por cada agregado familiar, e mesmo assim, esses homens de chapéu passavam as tardes de Domingo a imaginar as velhas casas verdes entre limos. De quando em quando faziam esperas na barragem e matavam-se. Era uma resistência incontrolada. (Jorge, 1992, p. 116117)

A incompreensão do fato social estender-se-á para o campo das relações afetivas. A Casa do Leborão, inicialmente promessa de espaço idílico do amor, transforma-se em território de inquietação, questionamento e dissolução, desestabilizando os planos do engenheiro, tumultuando os pensamentos da personagem, levando-a para múltiplas e obscuras zonas sentimentais, alegorizadas na composição espacial labiríntica da habitação. Da submissão à violência, passando pelo arrependimento e indiferença, Geraldes está convicto de que deve mudar sua situação, abandonando família e profissão, convencido pela estada na Casa. Para o engenheiro, os cinco dias na Casa com Ana Palma superam sua existência anterior, reduzida à rotina e monotonia. $\mathrm{O}$ desenlace trágico impede-o de seguir seus projetos, deixando Geraldes à deriva, circulando ininterruptamente em torno do ambiente em busca das razões para o acontecimento fatal. Os cinco dias na Casa de Leborão, rememorados por Geraldes, embriagam a personagem, modificando-a em seus valores e opções, aceitos durante anos. A crise do discurso masculino é enfatizada em $A$ última dona.

$\mathrm{O}$ romance $A$ última dona destaca um aspecto que se repete em outras narrativas de Lídia Jorge: a casa como constituição alegórica e simbólica da identidade nacional ${ }^{8}$. Dá sequência às preocupações da autora com o sentido do espaço que acaba por acionar e disseminar valores, ancorado em distintas concepções ideológico-artísticas. A variedade e extensão territoriais concorrem com a presença de espaços menores que, qualificados por objetos múltiplos, sinalizam uma característica significativa da natureza da escrita jorgeana: o estímulo à compreensão da realidade social através da alegoria e do símbolo.

Diferentes Portugais, representados em etapas históricas específicas, podem ser observados na "Casa do Leborão", na "Casa da Arara" e na "Casa de 
Valmares", respectivamente presentes em $A$ última dona, O jardim sem Limites e $O$ vale da paixão. Acrescente-se ainda, embora não receba nomeação própria, a casa onde residem as personagens Carminha e sua mãe, em $O$ dia dos prodígios e o ateliê onde vive Júlia Grei, local de partida para a reconstrução da identidade da jovem, em Notícia da cidade silvestre.

A purificação do espaço, através da limpeza diária da casa por Carmem, em $O$ dia dos prodígios, alegoriza uma identidade que, maculada, necessita ser "lavada" a fim de alcançar acolhimento". A sujeira e as nódoas, inscrições do passado, devem ser eliminadas, possibilitando a abertura para novos e promissores encontros sonhados. Em Notícia da cidade silvestre, o ateliê onde reside a personagem Júlia Grei, traduz precariedade material e emocional; portanto, a saída daquele espaço oportuniza, inicialmente, rumo novo à identidade da personagem, desvencilhando-se dos objetos do passado que, embora significativos, impossibilitam independência e maturidade.

Tais "casas" informam múltiplos sinais para a compreensão das subjetividades e identidades em jogo. Igualmente são registros fotográficos exemplares da historiografia social e política do País. Tais fisionomias arquitetônicas devem ser revistas para que não sejam outra vez cercadas pela loucura da guerra e do arbítrio.

O declínio econômico e político do salazarismo, regido pelo medo, silêncio e opressão, está representado na Casa de Valmares, território emblemático em que se entrecruzam três distintas referências ideológicas, alegorizadas pelas personagens Francisco Dias, o filho Walter Glória Dias e sua filha, detentora da voz narrativa que reavalia o passado à luz de objetos e depoimentos deixados pelo pai e familiares. Os sintomas do autoritarismo refletem-se nas três personagens. Da absoluta adequação ao período, encarnada por Francisco, à inquietação de Walter, passando pela busca incômoda e necessária da construção de identidade de sua filha, a Casa vai mostrando lentamente as fissuras causadas pelo preconceito, pelas diferenças e o tempo. A casa, defendida por Francisco Dias como "uma empresa sólida, uma unidade de produção à semelhança do estado" é revista com amargura e ironia pela filha de Walter.

O passado e a ausência de Walter também assombram a casa, provocando temores que, mesmo calados à força, aparecem somatizados no corpo familiar. A digestão incômoda de sua figura precisa ser realizada. A reescrita da presença de Walter Dias na casa é feita pela filha que recompõe episódios, submetidos ao esquecimento por um secreto conluio familiar. A filha de Walter realiza a desconstrução imagética da casa, reinaugurando-a sob outras perspectivas. Ao mesmo tempo, desconstrói a identidade paterna, para, em seguida, buscar a sua, negada como filha.

A falta de uma filiação segura emerge repetidamente à medida que a personagem principal recusa a unidade familiar dos Dias, procurando no manto militar do pai ausente a origem identitária. Em $O$ vale da paixão, a trajetória das personagens equivale, em muitos planos, à da nação portuguesa, descrita entre a dissolução do modo de vida rural, tradicional e pré-revolucionário alegorizado pela casa dos Dias, em Valmares - cujos filhos, exceto Custódio, emigram -, e a igualmente problemática ausência de referências, produzida pela dispersão pósrevolucionária.

Em O jardim sem Limites, uma nova ética artística e social é exposta na "Casa da Arara", reflexo do estado social português, afetado por uma nova ordem econômica mundial. A casa, pertencente à família Lanuit, agrega em seu espaço 
jovens personagens em busca da fama. Distantes do convívio familiar, os jovens inquilinos procuram, através de atividades inusitadas, inserir-se socialmente. Localizada na Baixa lisboeta, a "Casa da Arara" hospeda, entre outros, filhos da pequena burguesia que, sem recursos, porém sonhando com a independência financeira, acabam abastecidos regularmente pelas famílias a fim de que possam realizar seus projetos.

As personagens Eduardo Lanuit e sua esposa Julieta, donos da "Casa da Arara" e os jovens inquilinos Leonardo, Paulina e Falcão, são destaques. Os inquilinos são representações paradigmáticas do descrédito político e desalento coletivo. $\mathrm{O}$ engajamento em atividades político-partidárias, referência simbólica ao imaginário social da juventude em outro período, perde expressão, cedendo espaço a um comportamento voltado para ações econômicas e individuais ${ }^{10}$.

Em contrapartida às opções dos jovens inquilinos, a personagem Eduardo traduz o sentimento da possibilidade inquestionável de uma sociedade justa e igualitária. Ex-revolucionário de esquerda nos anos 60/70, vê-se vencido por outro contexto que o leva ao isolamento, transformando-o em sujeito marginal. Seu esforço em não pactuar com o sistema a fim de perpetuar suas crenças políticas torna-se patético e comovente. Desencantado com as adesões ao modelo econômico por parte dos ex-companheiros de luta, Eduardo Lanuit rabisca nas paredes da casa um quadro estatístico sintético em que avalia e julga o comportamento dos companheiros de outrora, qualificando-os de traidores, embriagados pela competição e lucro desenfreados, valores disseminados pelo contexto político presente.

O isolamento espacial - vive num casebre agregado ao casarão - e ideológico de Eduardo é contraposto pela esposa Julieta que, sonhando em consumir novos produtos oferecidos pelo mercado, recorre aos ex-companheiros de Lanuit para que esses consigam uma colocação profissional para o marido. Ao empreender secretamente a busca de emprego regular para o esposo, a personagem expõe-se ao assédio dos conhecidos que atuam em cargos diretivos de grandes corporações empresariais e financeiras. Ao tomar conhecimento do fato, Eduardo revolta-se, reafirmando sua confiança num trabalho executado em segredo. O trabalho é recusado, pondo em questão as estratégias, métodos e ideias, culminando na dissolução do casamento e na aplicação inadequada do legado ideológico da personagem.

A resposta simbólica à natureza ideológica de Lanuit é a atividade desenvolvida pelo jovem Leonardo que incorpora a personagem Static Man cuja tarefa consta em permanecer voluntariamente imóvel maior tempo possível. A personagem segue um ritual sistemático de exercícios, assessorado pela jovem Paulina, espécie de empresária do garoto, que pretende transformá-lo num artista de fama internacional. Paulina encoraja o amigo a árduas dietas e prolongadas ginásticas, compensadas ao proporcionar ao jovem o recorde mundial em "imobilidade voluntária"11. A recusa do prêmio levada a cabo por Leonardo acontece após seu contato com a personagem Ricardo Asse, poeta que interpreta os exercícios do garoto como alegorias da atividade poética, observando similaridades metodológicas entre as duas práticas. As relações do escritor com Leonardo aceleram o rompimento com Paulina.

A reaproximação de Paulina com Leonardo ocorre quando outro jovem inquilino da Casa da Arara, o protocineasta Falcão, sugere que Static Man atue num filme. A realidade deve ultrapassar a construção imagética, deixando ao espectador registros com a mínima manipulação narrativa. O desenlace trágico transforma-se 
em espetáculo, preconizando a discussão dos limites éticos da intencionalidade artística. As ideias em torno de um cinema-reportagem norteiam as noções de arte de Falcão. Sua cinematografia pretende a valorização de imagens cruas, sem o artificialismo artístico:

acreditava no filme ao vivo, um novo cinema directo capaz de colher a arte da bruteza real da vida, queria antes de mais e em primeiro lugar, transformar-se num verdadeiro repórter. Se [Orson]Welles estivesse naquele instante a nascer, pensaria como ele, saberia que a grande mudança estaria na colheita bruta da realidade, sem idéia prévia, sem scriptum, sem representação.(Jorge, 1995, p. 61)

Auxiliado por outros jovens da casa, Falcão procura capturar cenas de assassinatos, suicídios, psicopatas criminosos, serial killers portugueses, manifestações que informam uma Lisboa violenta, sob os efeitos do desordenamento moral e econômico, induzido por relações de produção operadas por novos níveis de hierarquia e sujeição. A paisagem urbana acolhe novas personagens que, sujeitas à incerteza, insegurança e medo, refugiam-se numa ética artística e comportamental duvidosas.

Em O jardim sem limites, tais manifestações refletem um novo tempo português, marcado por dilemas locais, regionais e nacional em vista da crescente aceleração e dominação política empreendida pela globalização econômica capitalista, sob o comando hegemônico norte-americano. Em tal ordenamento, multiplicam-se espaços de contato - real ou não -, instigando materialidades e desejos novos, tornando outros obsoletos ou ainda hibridizando-os, numa estrutura polifônica artificial universal. $O$ desconforto provocado pela desterritorialização ilimitada está sinalizado a partir do título do romance. Todavia, as fronteiras dissipadas motivam, paradoxalmente, a invenção de novas produtividades coletivas locais, acentuando possibilidades de reflorescimento identitário, ainda que vistos com ironia. Como salienta Boaventura de Souza Santos (2002, p. 45), "uma economia e uma cultura cada vez mais desterritorializadas só podem ter como resposta a reterritorialização, a redescoberta do sentido do lugar e da comunidade, das actividades produtivas de proximidade."

Ainda sob balizamento histórico-espacial, ocupam importância o Hotel Stella Maris e o Hotel Alguergue, respectivamente presentes em $A$ costa dos murmúrios e em $O$ cais das merendas. O domínio e o declínio colonial português na África são representados pelo primeiro que, da ostentação à decadência, abriga riqueza e alegria, contraditadas pela violência política e a miséria que cercam a vida do empreendimento arquitetônico ${ }^{12}$. O Hotel Alguergue alegoriza um tempo social em mutação que afeta, de forma contraditória, uma comunidade rural do Algarve, trazendo esperança e desgraça. Os dois eixos, representantes do modo como é acolhido o hotel na comunidade, são as personagens Sebastianito Guerreiro e sua filha Rosária. As marcas da desterritorialização são apreendidas contraditoriamente, motivando medo, inquietação e ousadia. Tragédia e euforia assinalam a presença daquele monumento.

A compreensão e solução de tais sentimentos são buscadas na figura da paixão e da escrita, sobressaindo-se outras características do discurso ficcional de Lídia Jorge. A paixão e a escrita afetam as relações amorosas, artísticas e políticas. 
As personagens de Lídia Jorge, ao envolverem-se plenamente em tais esferas, potencializam transformações, mas igualmente experimentam o arrefecimento do entusiasmo, dando marcha, muitas vezes, à decepção. Tais espaços são vividos com intensidade dialética, sem, contudo, formalizarem uma síntese definitiva, ainda que esta possa ser admitida na elevação da escrita e na representação da prática artística.

A paixão amorosa contamina as principais personagens, dificultando o distanciamento diegético. Há cumplicidade do leitor com os amores vividos. Em $O$ cais das merendas, o embriagamento amoroso de Sebastianito Guerreiro pela inglesa Miss Laura, hóspede do Hotel Alguergue, silenciosamente ruminado pelo ex-camponês, contagia, ainda que as ilusões amorosas da personagem sejam evidentes. O encantamento da turista estrangeira entorpece Sebastianito, metáfora da identidade enfeitiçada pelas formas de ser e estar estranhas, hibridizadas, no entanto, pela cultura local.

Em contrapartida à simplicidade das formas nacionais, estampada na alegoria de um "cântaro roliço", rememorado por Sebastianito na figura da esposa, ou ainda pelas formas "prensadas e lisas" das manequins de revista, há a evocação mágica da imagem de miss Laura, encarnação ao vivo das coisas férteis e abastadas e do equilíbrio instável e sutil das opulentas e diferentes partes do corpo. Em que pese a altura e o volume disforme da amante, o surpreendente era o corpo unir-se por "cinturinhas estreitas como se fosse miss Laura quebrar por aí.". A embriaguez se encerra, sobretudo, nas ancas que "meneavam como uma verdadeira fala", a sacudir-se "ligeiras e abauladas no fundo dos quadris em arco em volta, como garrafinhas de mateus rosé mas em ponto grande." A idealização de um outro espaço identitário é construída pela mistura da narrativa corporal à das relações nacionais e culturais, revistas dinamicamente. O mapeamento nacional é perseguido através do corpo feminino, ineditamente estruturado.

A personagem Júlia Grei, em Notícia da cidade silvestre, e o engenheiro Geraldes, de $A$ última dona, ao experimentarem a paixão, revelam igualmente a importância desse poderoso sentimento. Vivida em breves instantes da vida, a paixão triunfa sobre a convenção, incendiando pensamento e memória das personagens apaixonadas. Em A última dona, o engenheiro Geraldes, casado por longos anos, procura reaprender o amor apaixonado, libertando-se dos sentidos ditados pelo trabalho regular e pela família. A tragédia sabota o sonho almejado.

A paixão por Artur Salema motiva Júlia Grei a romper com o passado. Júlia é seduzida pelo romantismo político de Salema que encoraja a jovem a observar a sociedade sob outro ângulo, buscando, através de pequenas ações, a transformação do comportamento humano e da realidade. O despojamento e o voluntarismo de Salema atraem a moça, embriagando-a por completo, semeando a possibilidade amorosa. Todavia, em meio à embriaguez, alegorizada na "campânula de vidro", a paixão converte-se em frustração. As recusas dos projetos de Salema tornam o jovem cético, levando-o a abandonar o país, criando desalento à Júlia.

O discurso irônico encobre, então, a paixão amorosa e política. Diante das personagens apaixonadas, o romance paródico-irônico de Lídia Jorge narra os sentimentos com distanciamento crítico ao entrelaçá-los às condições históricas, para que os mesmos não sejam engolidos num excessivo ufanismo. $\mathrm{O}$ romantismo e o ceticismo absolutos são desacreditados por sua narrativa. A autora remete-nos a uma escrita que se alterna entre a emoção e a reflexão, dando verossimilhança às 
ações e pensamentos de suas personagens. Não há sobreposição da representação do objeto escrita sobre os eventos narrados.

Embora o plano da história - enunciado - seja destacado, Lídia Jorge também preocupa-se com a representação do discurso - enunciação -, informando o papel da escrita e seus diversos meios na elaboração. Em O jardim sem limites, a Casa da Arara acolhe importante personagem que, com aparente distanciamento e evasão, acompanha as filiações e trajetórias artístico-ideológicas dos membros daquele lugar. A inquilina, refugiada num dos quartos da Casa, denominado de "quarto da Remington" pelos demais moradores - referência à máquina de escrever pertencente à personagem -, desmascara as múltiplas intenções dos jovens, anunciando, ao mesmo tempo, a paixão pela escrita:

as teclas da Remington, repercutindo-se em duplo, transformavam as palavras que escrevia num ruído poderoso e triunfal. Não, nunca ninguém me veio bater à porta pelo barulho da máquina. Ou se vieram, não senti. Nessa altura eu tinha um projeto mais amplo do que o meu próprio alcance, e caminhava na escrita com o passo bruto do cavalo. Queria tudo - avançava estudando a estrada e levantando a poeira, gozando ao mesmo tempo da solidão do percurso como se fosse um álcool. (Jorge, 1995, p. 05)

A metáfora da escrita relacionada ao trotar rude do cavalo e à solitária embriaguez alcoólica estende-se a outros fenômenos discursivos e artísticos, experimentados pelas personagens da autora. A linguagem artística - do texto escrito à imagem fotográfica e cinematográfica - é traçada a partir de duas direções complementares que se entrecruzam de forma intermitente e problemática: a natureza e função da arte e o compromisso ético do artista.

Os romances polifônicos de Lídia Jorge preconizam o discurso artístico como atividade engajada, derivando-a, no entanto, de uma perspectiva paródica que multiplica, através do recurso irônico e metaficcional, a representação da realidade. A palavra como fiadora exclusiva da verdade histórica global é comprometida pelo drama da contradição, da memória múltipla e dinâmica que problematiza e desconstrói afirmações únicas e definitivas acerca do caráter das personagens e suas representações ideológicas.

O conhecimento científico, artístico, filosófico, religioso, etc., é problematizado pela escrita livre que, mediada pelas circunstâncias históricas, funciona como alternativa aos desconcertos do mundo individual e coletivo. A escrita polifônica jorgeana provoca tensões contínuas que conduzem ao posicionamento ético-político em permanente contradição. As personagens descobrem em tal recurso não somente uma forma de distensão emocional e afirmação identitária, mas igualmente conferem às palavras um tratamento ideológico exemplar que questiona a neutralidade ética do artista.

Ao comentar sobre as relações entre ética e produção artística, Paul Ricoeur (1994, p. 95) interroga: "a neutralidade ética do artista não suprimiria uma das mais antigas funções da arte, a de constituir um laboratório em que o artista leva adiante, por intermédio da ficção, uma experimentação com valores?” A experiência com valores, disseminada contraditoriamente, percorre a obra de Lídia Jorge. Concepções ideológico-artísticas variáveis e em conflito são representadas. Nesse sentido, tem razão o filósofo, ao comentar que "qualquer que seja a resposta, a poética não cessa de tomar empréstimos da ética, até mesmo quando 
prega a suspensão de qualquer juízo moral ou mesmo a sua inversão irônica." (ibidem, 95) O projeto de neutralidade pressupõe a qualidade ética da ação, simbolicamente mediada.

A mediação simbólica é a escrita que, com seus múltiplos recursos, tornase ferramenta essencial para as personagens femininas. Eva Lopo, Julia Grei e as intérpretes de $O$ jardim sem limites e $O$ vale da paixão dedicam a escrita a exercícios de reflexão e compreensão, praticando-a em cadernos, diários, cartas, apontamentos. Através da confissão escrita, procuram defender-se das dúvidas e dívidas, pessoais e coletivas, projetando valores que desafiam os regimes de verdade, praticados em nome da História oficial. Ao interlocutor, Júlia confessa a sedução da escrita que parece suspender o real, tornando-o, paradoxalmente, mais vivo e claro:

Como sabe, possuo um monte de papel à mão, e assim que tudo sossega, deslizo pela folhas a ronceira da esferográfica. É tudo o que tenho feito. Quando isso acontece, o mundo abre, fecha sua cortina, a vida transfigura-se. Todos os seres em casa se põem parados. E essa paragem é tão física e tão real que até o pó parece deixar de cair, a meio caminho entre as frinchas e as coisas, aí quieto, suspenso no ar à espera. Só quando me levanto ele sobe, desce e pousa. O papel é um tecido doce, humano e envolvente como uma pele. (Jorge, 1984, p. 353-354)

Nas obras de Lídia Jorge, há, grosso modo, duas maneiras de encarar a arte, funcionando ambas positiva ou negativamente, conforme o acolhimento ideológico da recepção. Ao representar o discurso artístico e sua função em suas narrativas, a autora "trabalha" numa perspectiva calculadamente crítica que absorve, com ironia e emoção, as contradições e os desafios a que está submetida a atividade do artista. Assim, as personagens Artur Salema e Fernando Rita, Leonardo e Falcão, entre outros, acentuam "modelos" em conflito que encarnam distintamente o fazer artístico.

As concepções divergentes não invalidam a crença da importância do testemunho particular da arte como forma de questionamento simbólico e alegórico da história social e individual. Em Notícia da cidade silvestre, Fernando Rita, empenhado em sua obra, aparece como paradigma importante quanto à função utópica do artista, correspondendo às declarações das narradoras mulheres já mencionadas. O jovem escultor persegue a feitura do objeto com paciência, atendendo ao ensinamento do seu mestre João Martinho: "A arte sempre será uma prova de paciência”. (ibidem, 1984, p. 70)

Em que pese a mediação irônica, o entusiasmo conferido à escrita e à arte é enorme, à medida que elas assumem a profecia da revisitação do corpo, particular e coletivo, que, submetido às relações de poder, é metaforicamente rasurado, assaltado, conspurcado, profanado, desmaterializado para dessa excursão poético-terapêutica ressurgir livre e responsável, fundando, ao seu modo, novas identidades narrativas: dinâmicas, múltiplas, dissonantes e situacionais. A escrita artística realiza o trabalho de luto identitário, ocupando, dessa forma, espaço específico no questionamento dos indivíduos e sociedade.

Os romances de Lídia Jorge são manifestações simbólicas e alegóricas de um Portugal em transformação. Os diferentes espaços - históricos, sociais e geográficos -, mediados pela escrita, carregam consigo a tensão das relações sócioafetivas, ensejando encontros ou desencontros familiares e amorosos. Objetos 
fantásticos ou não auxiliam no redimensionamento metafórico das identidades pessoal e coletiva. Tais elementos funcionam como extensão das expressões afetivas dos sujeitos. São estatutos do corpo narrativo que potencializam o ver e o sentir, ampliando os significados da realidade imediata. Como destaca Walter Benjamin (1984, p. 196), numa perspectiva alegórica, "cada pessoa, cada coisa, cada relação pode significar outra". Nesse sentido, o mundo profano é ao mesmo tempo exaltado e desvalorizado, investido de poderes plurissignificativos que o fazem aparecer incomensurável. Na obra de Lídia Jorge, a multiplicidade de sentidos espacio-temporais é preenchida ainda pela recorrência a sons, aromas e cores, oferecendo um enquadramento pleno da ambientação. Em $A$ costa dos murmúrios, Eva Lopo contraria os materiais utilizados pelo artista numa escultura em que pretende representar o massacre de negros africanos, vítimas da violência e da dominação colonial portuguesa. Para a personagem, a "escultura exacta deveria ser uma amplo caldeirão de fezes, evolando-se permanentemente, não como símbolo, mas como matéria real do nosso mais amplo e subtil sofrimento".(1988, p. 255)

A romancista escreve sob o signo das territorialidades identitárias em transição, testadas na experiência viva do cotidiano, trazida à consciência dos sujeitos através da memória e da palavra. Os conflitos entre permanência e mudança, pressionados pelo entrecruzamento político-cultural, presentes na sua narrativa, encerram-se em torno de marcos históricos que balizam o romance português contemporâneo: o salazarismo, a guerra colonial e a Revolução dos Cravos. Lídia Jorge apresenta-os sob olhares múltiplos, delegando, em mais de uma ocasião, à visão da mulher os dramas da nacionalidade, revistos com ironia e emoção.

\section{NOTAS}

1. Além dos romances examinados no presente estudo, Lídia Jorge apresenta mais dois: O vento assobiando nas gruas (2000) e Combateremos a sombra (2007). O primeiro aborda o encontro de duas famílias que representam posições culturais e políticas distintas em território português. Composta por imigrantes oriundos do arquipélago de Cabo Verde, a família Mata vivencia o impacto da sociedade de consumo e as alternativas proporcionadas pela cultura de massa em Portugal. Os Leandros, antiga família tradicional e de prestígio durante um período importante da vida nacional portuguesa no século XX que, paulatinamente, experimentou o declínio econômico, procura manter-se economicamente à custa de negócios, nem sempre transparentes, conduzidos pelos tios. A ex-fábrica de conserva Leandro é o espaço que dá início aos conflitos de classe e cultura que demarcarão a estrutura narrativa, "vitimando" duas personagens: a portuguesa branca Milene e o operário negro Antonino da Mata. O romance Combatermos a sombra gira em torno das relações afetivas entre o psicanalista Orlando Campos e seus pacientes. Desses destacam-se, entre outros, as personagens Maria London Loureiro, Rossiana Inácio e o angolano Lázaro Catembe. Este último busca ajuda ao médico devido a um "curioso" trauma: não "reconhece" os seus compatriotas quando estes estão dirigindo os coletivos públicos nas ruas de Lisboa. Ao deparar-se com um deles, descontrola-se, acusando-o de selvagem. Um dos espaços centrais é o edifico Goldini onde se localiza o consultório de Orlando, lugar em que as múltiplas 
histórias dos pacientes vão sendo tecidas para o deleite dos leitores do romance. Como se destaca no decorrer do presente ensaio, predomina, nestes dois romances, a crítica de Lídia Jorge às desigualdades econômicas, o não reconhecimento das diferenças culturais e à exacerbação do consumo cultural.

2. A remoção e permanência da pedra alguergue próxima ao local onde está o hotel simula uma nova ordem dada à natureza e à região. Antropofagizada pelo olhar dos agentes de produção, a pedra aparece como fenômeno estético do que em elemento da tradição local. A tragédia é a resposta irônica ao enxerto da pedra promovido pelos construtores do hotel. Nova estratégia narrativa é adquirida pela pedra, modelando juízo estético dos freqüentadores do local. A natureza é parodiada e ultrajada em sua essência. Ao deixar a pedra em seu lugar de origem, os agentes produtores respeitam os valores das populações locais, adaptando-os em nova modelagem. Tal posição, defendida por grupos econômicos e grandes corporações transnacionais, é destronada por Lídia Jorge ao fazer emergir da pedra o desencanto de uma identidade conspurcada.

3. A utilização da língua inglesa em detrimento do português e das derivações dialetais locais é um aspecto central do romance. A personagem Zulmira Santos preconiza o uso da palavra "partie" em vez de "merenda", cujo significado está circunscrito às festividades rurais realizadas pelos camponeses da região ao comemorarem a produção do trabalho agrário. $\mathrm{O}$ termo refere-se igualmente ao período de descanso, intervalo vivido após plantações e colheitas. A substituição do termo merenda por "partie" denota uma transformação ideológica do perfil dos moradores.

4. A personagem Eva Lopo recorda "que ninguém falava em guerra com seriedade. O que havia ao Norte [de Moçambique] era uma revolta e a resposta que se dava era uma contra-revolta. Ou menos do que isso - o que havia era banditismo, a repressão do banditismo chamava-se contra-subversão. Não guerra."(p. 74)

5. Como destaca uma das personagens do romance: "o tiro é a síntese da História." (p.80)

6. Guy Debord destaca: "considerado em sua totalidade, o espetáculo é ao mesmo tempo o resultado e o projeto do modo de produção existente. Não é um suplemento do mundo real, uma decoração que lhe é acrescentada. É o âmago do irrealismo da sociedade real. Sob todas as suas formas particulares - informação ou propaganda, publicidade ou consumo direto de divertimentos -, o espetáculo constitui o modelo atual da vida dominante na sociedade. O espetáculo é o capital em tal grau de acumulação que se torna imagem."(DEBORD, G. A sociedade do espetáculo. Rio de Janeiro: Contraponto, 1997.)

7. Igualmente emblemático é o suicídio da adolescente Rosária, personagem de $O$ cais das merendas. O salto mortal dado do alto do Hotel Alguergue em direção à pedra que dá nome à construção, responde à crise identitária da garota, dividida entre as formas tradicionais e modernas de ocupação do espaço A morte da jovem sintetiza a queda de um modelo específico de país, substituído pelo incremento de novas relações produtivas e culturais.

8. Importante destacar o projeto de pesquisa "A casa portuguesa: uma forma de escrever Portugal", do ensaísta, pesquisador e professor Jorge da Silveira em que, através da leitura de textos de narrativa, poesia e ensaio, realiza reflexões em torno da metáfora da construção da casa como uma forma de pensar Portugal por meio da escrita. Como salienta Jorge da Silveira, numa cultura marcada pela viagem, pelo exílio, pela imigração, a idéia é perceber de que maneira o "escritor português representa nas casas de escrita a busca obsessiva 
do espaço.”(In: SILVEIRA, Jorge. (org.) Escrever a casa portuguesa. Belo Horizonte: UFMG, 1999, p.18.)

9. A argumentação refere-se às constantes e contínuas lavagens das vidraças para tirar os resíduos deixados pelas moscas - figuras identitárias do Alagarve - impurezas que devem ser extirpadas daquele território.

10. Zygmunt Bauman alerta que a "individualidade é uma fatalidade, não uma escolha", uma vez que sua experiência é resultado sempre de uma arranjo social. A liberdade conferida ao indivíduo possui um destino prévio, estabelecido pelo modo de produção social. Para o sociólogo polonês, "o indivíduo não pode se tornar indivíduo de facto sem antes tornar-se cidadão. Não há indivíduos autônomos sem uma sociedade autônoma, e a autonomia da sociedade requer uma autoconstituição deliberada e perpétua, algo que só pode ser uma realidade compartilhada de seus membros.” (BAUMAN, Zygmunt. Modernidade líquida. Rio de Janeiro: Jorge Zahar, 2001, pp. 23-63.)

11. A parodização da identidade social e cultural de Portugal é realizada através do feito conquistado pelo garoto. A paródia ao exotismo que caracteriza muitos discursos acerca da identidade nacional, estende-se ao fato, signo exclusivo de reconhecimento externo do País, dando seqüência aos valores disseminados pelo salazarismo: Portugal como figura única e exemplar no contexto europeu e ocidental

12. Como recorda a personagem Eva Lopo, o Hotel Stella Maris era importante, pois "teria bastado esse belo nome de evocação marítima, brilhando acima das palmeiras para que tivesse a sua importância," mas havia outras razões, entre as quais, a presença de "homens abastados que desciam pelos Trans-Zambeziam Railways, vinham espalhar até a década de cinqüenta, as inumeráveis malas, os longos dentes de elefante. Antes de tomarem os paquetes e partirem a negociar em língua inglesa. $O$ sussurro dum tempo colonial doirado vinha ali aportar, e por isso ainda se falava do modo como as banheiras primitivas eram assentes no chão por pés em forma de garra. Nessa altura, ainda os negros não podiam, ou não queriam, encontrar os colonos brancos no mesmo passeio das ruas. (A costa dos murmúrios, p.44)

\section{REFERÊNCIAS BIBLIOGRÁFICAS}

BENJAMIN, Walter. Origens do drama barroco alemão. São Paulo: Brasiliense, 1984.

DOSSE, François. A história à prova do tempo: da história em migalhas ao resgate do sentido. São Paulo: Unesp, 1999.

JORGE, Lídia. O dia dos prodígios. Lisboa: Dom Quixote, 1980. . O cais das merendas. Lisboa: Dom Quixote, 1982. . Notícia da cidade silvestre. Lisboa: Dom Quixote, 1984. - A costa dos murmúrios. Lisboa: Dom Quixote, 1988. - A última dona. Lisboa: Dom Quixote, 1992. . O jardim sem limites. Lisboa: Dom Quixote, 1995. . O vale da paixão. Lisboa: Dom Quixote, 1998.

RICOEUR, Paul. Tempo e narrativa. V. I. Campinas; SP: Papirus, 1994. . Tempo e narrativa. V. III. Campinas; SP: Papirus, 1997. 